\section{Preliminary Results for Street Racing Among Adults in Ontario: Relations to Alcohol and Cannabis Use}

Dear Editor:

Street racing has a long history, dating back to the 1920s shortly after cars became cheap, plentiful and available to the masses. Many movies and songs idolize street racers, e.g., "Rebel Without a Cause" and "The Fast and the Furious". There have been several recent instances where street racers or innocent bystanders have been fatally injured. Street racing is now a problem in countries worldwide, with deaths and injuries reported in many. ${ }^{1,2}$ However, little is known about the factors associated with this behaviour. We examined street racing and its links to various alcohol and cannabis measures among adults in Ontario.

We employed data from the Centre for Addiction and Mental Health Monitor (CM), a general population telephone survey conducted in Ontario (January 2009 to December 2010). The survey consists of a representative sample of adults (aged 18 and older) who were asked if they had driven a car, truck or SUV in a street race in the previous 12 months $(\mathrm{N}=4,273) .{ }^{3}$ Demographic and substance use measures were also collected in the survey.

Results from preliminary analyses (see Table 1) revealed that the prevalence of self-reported street racing within the previous year was $1.0 \%$, and was significantly related to sex, age, alcohol problems ( $8+$ on the Alcohol Use Disorders Identification Test, AUDIT), heavy drinking (monthly drinking of 5+ drinks on one occasion), cannabis use and drinking driving. Street racing was most commonly reported by males between the ages of 18 and 34 (4.5\%, 95\% CI 2.5-7.9), drinking drivers (5.5\%), respondents with an alcohol problem $(3.0 \%)$, respondents who used cannabis in the previous 12 months (3.0\%), and heavy drinkers (1.9\%). It was found that, compared to non-racers, those who engaged in street racing were five times as likely to have alcohol problems, seven times as likely to drink and drive and four times as likely to use cannabis.
This study suggests that heavy drinking, alcohol problems, cannabis use and drinking driving are associated with street racing among adults. These characteristics are similar to those found for aggressive driving, road rage and other types of dangerous driving. ${ }^{4-6}$ The results given here are preliminary as they are not based on a large sample of street racers but rather a large sample of the population. Further studies are needed to extend and amplify these results, however in the meantime it appears that street racing is associated with both alcohol and other drug use in high-risk drivers.

Reginald G. Smart, ${ }^{1}$ Gina Stoduto, ${ }^{1 *}$ Evelyn Vingilis, ${ }^{2}$

Christine M. Wickens, ${ }^{1}$ Robert E. Mann ${ }^{1,3}$ Anca Ialomiteanu ${ }^{1}$

1. Social and Epidemiological Research, Centre for Addiction \& Mental Health, Toronto, ON

2. Schulich School of Medicine \& Dentistry, University of Western Ontario, London, ON

3. Dalla Lana School of Public Health, University of Toronto, Toronto, ON

* Author for correspondence: gina_stoduto@camh.net

\section{REFERENCES}

1. Knight S, Cook LJ, Olson LM. The fast and the fatal: Street racing fatal crashes in the United States. Inj Prev 2004;10:53-55.

2. Folkman L-M. Queensland's anti-hoon legislation and policing methods used to prevent hooning behaviour. Proceedings of the Australasian Road Safety Research, Policing and Education Conference, Wellington, New Zealand, 2005.

3. Ialomiteanu A, Adlaf EM. CAMH Monitor 2009 Technical Guide. Toronto: CAMH, 2010. Available at: www.camh.net/Research/Areas_of_research/Population_Life_Course_Studies/CAMH_Monitor/CM2009_TechDoc_final.pdf (Accessed July 11, 2011).

4. Smart RG, Mann RE, Goldbloom DS. Road rage: Are our patients driving angry? Psychiatric Times 2005;22(4):25-31. Available at: www.psychiatrictimes.com/showArticle.jhtml?articleID=162100161 (Accessed May 9, 2005).

5. Asbridge M, Poulin C, Donato A. Motor vehicle collision risk and driving under the influence of cannabis: Evidence from adolescents in Atlantic Canada. Accid Anal Prev 2005;37:1025-34.

6. Stoduto G, Dill P, Mann RE, Wells-Parker E, Toneatto T, Shuggi R. Examining the link between drinking-driving and depressed mood. J Stud Alcohol Drugs 2008;69:777-80.

Table 1. Street Racing by Sample Characteristics: CM January 2009 to December 2010

\begin{tabular}{|c|c|c|c|c|}
\hline \multirow{3}{*}{$\begin{array}{l}\text { Total } \\
\text { Sex*** }\end{array}$} & \multirow{2}{*}{$\begin{array}{c}\text { Sample } \\
\mathbf{N} \\
4273\end{array}$} & \multicolumn{3}{|c|}{ Street Racer } \\
\hline & & $\begin{array}{l}\mathbf{n} \\
32\end{array}$ & $\begin{array}{r}\% \\
1.0\end{array}$ & $\begin{array}{c}\mathbf{9 5} \% \mathbf{~ C I} \\
0.7-1.5\end{array}$ \\
\hline & \multicolumn{4}{|c|}{ Sex $* * *$} \\
\hline Males & 1916 & 25 & 1.7 & $1.1-2.7$ \\
\hline Females & 2357 & 7 & 0.3 & $0.1-0.7$ \\
\hline \multicolumn{5}{|l|}{ Age (years) $)^{\star \star *}$} \\
\hline $18-34$ & 616 & 15 & 2.4 & $1.3-4.2$ \\
\hline $35-54$ & 1741 & 10 & 0.6 & $0.3-1.3$ \\
\hline $55+$ & 1832 & 7 & 0.5 & $0.2-1.2$ \\
\hline \multicolumn{5}{|l|}{ AUDIT $8+* * *$} \\
\hline No & 3681 & 17 & 0.6 & $0.3-1.0$ \\
\hline Yes & 520 & 12 & 3.0 & $1.6-5.7$ \\
\hline \multicolumn{5}{|c|}{ Five plus drinking monthly - last 12 months* } \\
\hline No & 3529 & 21 & 0.8 & $0.5-1.3$ \\
\hline Yes & 725 & 10 & 1.9 & $0.9-3.9$ \\
\hline \multicolumn{5}{|c|}{ Weekly alcohol volume consumed (drinks) mean (sd) } \\
\hline Non-street racer & & & $3.63(6.97)$ & $3.39-3.87$ \\
\hline Street racer & & & $5.45(6.29)$ & $3.06-7.85$ \\
\hline \multicolumn{5}{|c|}{ Drinking driving - last 12 months $* * *$} \\
\hline No & 3989 & 22 & 0.7 & $0.4-1.2$ \\
\hline Yes & 249 & 10 & 5.5 & $2.7-10.9$ \\
\hline \multicolumn{5}{|c|}{ Cannabis use - last 12 months ${ }^{* * *}$} \\
\hline No & 3784 & 19 & 0.7 & $0.4-1.2$ \\
\hline Yes & 453 & 13 & 3.0 & $1.6-5.3$ \\
\hline \multicolumn{5}{|c|}{$\begin{array}{l}\text { Notes: } \mathrm{N} \text { is the number of unweighted cases and \% is the percentage of subgroups of each variable based on weighted data. All analyses are sample design } \\
\text { adjusted. } 95 \% \mathrm{Cl}=95 \% \text { confidence interval. Comparisons of street racers and non-street racers on each variable were performed using STATA. Chi-square and } \\
\text { t-test significance: }{ }^{*} \mathrm{p}<0.05{ }^{* *} \mathrm{p}<0.01{ }^{* * *} \mathrm{p}<0.001 \text {. } \\
\mathrm{CM}=\text { Centre for Addiction and Mental Health Monitor. }\end{array}$} \\
\hline
\end{tabular}

